\title{
Detectability analysis of open phase condition in Korea's standard nuclear power plant
}

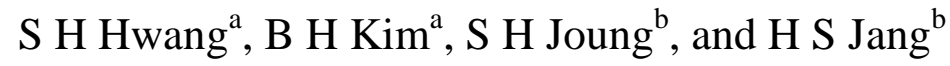 \\ ${ }^{a}$ Power Economics Lab, Hongik University, Seoul, Republic of Korea \\ ${ }^{b}$ Control \& Electrical System, Korea Institute of Nuclear Safety (KINS), Daejeon, Republic of Korea
}

\begin{abstract}
Currently, Open Phase Condition (OPC) on nuclear power system has been reported from various countries of the world and many nuclear regulatory agencies such as NRC require establishing a protective system of the power system that automatically detects the occurrence of OPC. Therefore, it is necessary to analyze the design suitability of protection system for OPC in Korean nuclear plant also. In this paper, the OPC for Korean standard nuclear plants is conspired using power system analysis program, ETAP and the detectability of protecting relay is analyzed.
\end{abstract}

Keywords: Open Phase Condition (OPC), Fault Detection, Protection, ETAP

\section{Introduction}

Open Phase Condition (OPC) is defined as the fault that one phase (or two phase) is maintained as open among three phases of power system for normal operation of the power system. When OPC occurs, unbalanced power is supplied to utilization (load) equipment and results in equipment failure or facility breakdown, which eventually leads to the non-operation of a power plant [1]. Over the last 20 years, there have been more than 13 OPC events around the world [2]. Of them, the event of Byron Station Unit 2 happened because no proper detection and protection system worked for OPC. It evidenced that when OPC takes place in an offsite power system, the existing protective relay system cannot sufficiently and completely protect a power plant from it in its every operation mode.

Accordingly, many nuclear regulatory agencies such as NRC require establishing a protective system of the power system that automatically detects the occurrence of OPC in all electrical configuration and operation modes and transmits an alarm to the main control room. [1][3][4]

In this paper, scenarios of offsite power loss by OPC, which may occur in the standard nuclear power plant in Korea are designed and analyzed the detectability of OPC event by an onsite protective relay by scenario. OPC event in the offsite power system was simulated by the power system analysis program, ETAP 12.6, which has been verified for its reliability in the analysis of the power system of nuclear power plants around the world.

\section{Operational Status of Onsite/Offsite Power System in Representative Nuclear Power Plants}

\subsection{Configuration of onsite/offsite power system}

Offsite power system consists of a $345 \mathrm{kV}$ switchyard. The main system includes a main generator (MG), a generator circuit breaker (GCB), a main transformer (MT), an isolated phase bus (IPB) and two unit auxiliary transformers (UAT). MG, UAT, and the Low-voltage side of MT are connected to one another through IPB. Meanwhile, for an onsite power system, it is divided into two sites. To each site, power can be supplied through UAT or a standby auxiliary transformer (SAT). The onsite power system consists of four Non-1E $13.8 \mathrm{kV}$ buses, four Non-1E 4.16kV buses, and two Class-1E 4.16kV buses. Each of Class-1E $4.16 \mathrm{kV}$ bus is connected to an emergency diesel generator (EDG).

\footnotetext{
* Manuscript received March 28th, 2018; revised April 30th, 2019.

doi: $10.12720 /$ sgce.8.4.443-452
} 


\subsection{Operation of onsite power system}

In a normal operation of a nuclear power plant, $\mathrm{MG}$ supplies power to loads of the class $1 \mathrm{E}$ and the Non-1E buses through UAT. In case MG is not in a normal condition and thus cannot supply power to the onsite power system, electricity of $345 \mathrm{kV}$ switchyard is rendered to the onsite load through MT and UAT while GCB is open. In case that power is not supplied through UAT, it is supplied to onsite class $1 \mathrm{E}$ and the Non-1E bus facility through SAT.

\subsection{Specification of power transformer}

Table 1 through 3 show the normal ratings of the electric transformer operating in each onsite power system.

Table 1. The normal ratings of main transformer (MT).

\begin{tabular}{ccc}
\hline \multirow{2}{*}{ Capacity } & \multicolumn{2}{c}{ Voltage $(\mathrm{kV})$} \\
\cline { 2 - 3 } & High-voltage & Low-voltage \\
\hline $\begin{array}{c}\text { 1060/1187MVA } \\
\text { (3) } 1 \text {-Phase }\end{array}$ & 345 & 20.9 \\
\hline
\end{tabular}

Table 2. The normal ratings of unit auxiliary transformers (UAT).

\begin{tabular}{ccc}
\hline & \multicolumn{2}{c}{ Voltage (kV) } \\
\cline { 2 - 3 } Capacity & High-voltage & Low-voltage \\
\hline P: $48.0 / 71.7$ MVA & & S: 14.49 \\
S: $32.0 / 47.8$ MVA & P: 22 & T: 4.47 \\
T: $16.0 / 23.9$ MVA & & \\
\hline
\end{tabular}

Table 3. The normal ratings of standby auxiliary transformer (SAT).

\begin{tabular}{ccc}
\hline \multirow{2}{*}{ Capacity } & \multicolumn{2}{c}{ Voltage $(\mathrm{kV})$} \\
\cline { 2 - 3 } & High-voltage & Low-voltage \\
\hline $\mathrm{P}=44.0 / 65.7 \mathrm{MVA}$ & & \\
$\mathrm{S}=29.0 / 43.3 \mathrm{MVA}$ & $\mathrm{P}: 345$ & $\mathrm{~S}: 13.8$ \\
$\mathrm{~T}=15.0 / 22.4 \mathrm{MVA}$ & & $\mathrm{T}: 4.16$ \\
\hline
\end{tabular}

\subsection{Specification of protective relay}

When OPC occurs on the high voltage side of a transformer, voltage unbalance takes place in the onsite power system and thus voltage and current at a reverse phase come to reside in the power system. In addition, because disconnected conductor due to open phase cannot convey power, it causes the loss of voltage. When the open phase conductor is accompanied with high-impedance ground fault, even zero sequence current generates.

Among existing protective relay systems for the relevant nuclear power plant, table 4 shows one detecting such OPC event. 
Table 4. Types of relays and protective measures.

\begin{tabular}{|c|c|c|}
\hline Protective Equipment & Protective Elements & Functions \\
\hline MG & $\begin{array}{l}\text { Negative sequence current relay } \\
\text { (346) }\end{array}$ & $\begin{array}{l}\text { Stage 1: SWYD PCP Trip } \\
\text { Stage 2: Alarm in the MCR }\end{array}$ \\
\hline MT & $\begin{array}{l}\text { Neutral overcurrent relay } \\
(551 \mathrm{GN})\end{array}$ & Alarm in the MCR \\
\hline SAT & $\begin{array}{l}\text { Neutral overcurrent relay } \\
(551 \mathrm{GN})\end{array}$ & Alarm in the MCR \\
\hline \multirow[t]{2}{*}{$\begin{array}{l}\text { Non-Class 1E Buses } \\
(13.8 \mathrm{kV})\end{array}$} & $\begin{array}{l}\text { Under voltage relay } \\
(227 \mathrm{M})\end{array}$ & Trip the MV Motor \\
\hline & $\begin{array}{l}\text { Under voltage relay } \\
\text { (227LS, LU) }\end{array}$ & Alarm in the MCR \\
\hline \multirow[t]{2}{*}{$\begin{array}{l}\text { Non-Class 1E Buses } \\
(4.16 \mathrm{kV})\end{array}$} & $\begin{array}{l}\text { Under voltage relay } \\
(127 \mathrm{M}, 127 \mathrm{~T})\end{array}$ & Tripping the MV motors \\
\hline & $\begin{array}{l}\text { Under voltage relay } \\
\text { (127LS, LU) }\end{array}$ & Alarm in the MCR \\
\hline \multirow[t]{4}{*}{ Class 1E Buses } & Under voltage relay & Starting EDG \\
\hline & $(127 \mathrm{P})$ & Trip Incomming Braker \\
\hline & $\begin{array}{l}\text { Degraded voltage relay } \\
(127 \mathrm{~S})\end{array}$ & Load Sequential loading \\
\hline & $\begin{array}{l}\text { Under voltage relay } \\
(127 \mathrm{LS}, \mathrm{LU})\end{array}$ & Alarm in the MCR \\
\hline $\begin{array}{l}\text { Non-Class 1E } \\
\text { and Class 1E Buses }\end{array}$ & $\begin{array}{l}\text { Negative sequence overvoltage relay } \\
(247,147)\end{array}$ & Alarm in the MCR \\
\hline $\begin{array}{l}\text { Non-Class } 1 \mathrm{E} \\
13.8 \mathrm{kV} \text { motors }\end{array}$ & $\begin{array}{l}\text { Negative sequence current relay } \\
(246)\end{array}$ & Tripping the MV motors \\
\hline
\end{tabular}

\section{OPC Event Simulations}

In this paper, based on the operational status above, power system analysis program, ETAP is used to model the power system of the target nuclear power plant and carried out OPC simulations by scenario. And based on the results, the detectability of each protective relay is analyzed. ETAP is a commercial software to analyze power system (e.g. power flow calculation, error calculation, harmonic, optimal power flow calculation, stability analysis, and protection coordination). In addition, the program has been used and proven in US nuclear power plants as well as the domestic nuclear power plants. [5]

\subsection{Designing OPC simulations}

\subsubsection{Location of OPC event.}

The relevant power plant supplies power to the onsite load through UAT or SAT, depending on its operational condition. Therefore, it is necessary to analyze all of two cases (power supplied through UAT and SAT).

\subsubsection{Types of OPC events.}

1-phase (with high-impedance ground fault or not) OPC and 2-phase OPC can occur when the insulation supports of the switchyard and bus break off or the circuit breaker fails. Therefore, three scenarios were designed as follows. 
- 1-phase OPC (without high-impedance ground fault)

- 2-phase OPC (without high-impedance ground fault)

- 1-phase OPC (with high-impedance ground fault)

\subsubsection{Operational modes of target nuclear power plant.}

When an OPC event occurs, the extent of voltage unbalance varies depending on an operation mode (load factor). Therefore, the power plant operation modes were set by the load factor of the transformer as in Table 5.

Table 5. The operational modes of target nuclear power plant set for OPC simulation.

\begin{tabular}{lll}
\hline Load Factor & Operation Mode & System Condition \\
\hline Heavily Loaded & Normal Operation & $\begin{array}{l}\text { MG supplies power to the onsite load through UAT and to the power } \\
\text { system network through MT. } \\
\text { Power is supplied to the onsite load from the power system network } \\
\text { through MT and UAT or SAT. } \\
\text { GCB is open. }\end{array}$ \\
\cline { 2 - 3 } Lightly Loaded & Minimum Loading & $\begin{array}{l}\text { Power is supplied to the onsite load from the power system network } \\
\text { through MT and UAT or SAT. } \\
\text { GCB is open. }\end{array}$ \\
\cline { 2 - 3 } No-Load Condition & Normal Operation & $\begin{array}{l}\text { In a normal operation mode, open phase fault on SAT high voltage } \\
\text { side is assumed to take place at no load. } \\
\text { When power is supplied to the onsite load through SAT, open phase } \\
\text { fault on MT high voltage side is assumed to take place at no load. }\end{array}$ \\
\hline
\end{tabular}

\subsubsection{OPC simulation scenarios.}

Table 6 shows the detailed scenarios of OPC simulation designed on the operation modes above. OPC events are divided into 1-phase open phase, 2-phase open phase, and OCP with high-impedance ground fault. It is presumed that ' $A$ ' phase is opened for 1-phase open phase, and ' $A$ ' / ' $B$ ' phase are opened for 2-phase open phase in case of problem type.

Table 6. Detailed scenarios of OPC simulations

\begin{tabular}{rlllll}
\hline $\begin{array}{l}\text { Case } \\
\text { No. }\end{array}$ & Operating Mode & Power Source & $\begin{array}{l}\text { Fault } \\
\text { Location }\end{array}$ & $\begin{array}{l}\text { Transformer } \\
\text { Loading }\end{array}$ & Open Phase \\
\hline 1 & Normal operation & MG, UAT & MT & Heavily loaded & A' phase open \\
2 & Normal operation & MG, UAT & MT & Heavily loaded & A, B' phase open \\
3 & Normal operation & MG, UAT & MT & Heavily loaded & A' phase (with high-impedance ground fault) \\
4 & Hot-standby & MT, UAT & MT & Heavily loaded & A' phase open \\
5 & Hot-standby & MT, UAT & MT & Heavily loaded & A, B' phase open \\
6 & Hot-standby & MT, UAT & MT & Heavily loaded & A' phase (with high-impedance ground fault) \\
7 & Hot-standby & SAT & SAT & Heavily loaded & A' phase open \\
8 & Hot-standby & SAT & SAT & Heavily loaded & A, B' phase open \\
9 & Hot-standby & SAT & SAT & Heavily loaded & A' phase (with high-impedance ground fault) \\
10 & Minimum loading & MT, UAT & MT & Lightly loaded & A' phase open \\
11 & Minimum loading & MT, UAT & MT & Lightly loaded & A, B' phase open \\
12 & Minimum loading & MT, UAT & MT & Lightly loaded & A' phase (with high-impedance ground fault) \\
13 & Minimum loading & SAT & SAT & Lightly loaded & A' phase open \\
14 & Minimum loading & SAT & SAT & Lightly loaded & A, B' phase open \\
15 & Minimum loading & SAT & SAT & Lightly loaded & A' phase (with high-impedance ground fault)
\end{tabular}




$\begin{array}{llllll}16 & \text { Normal operation } & \text { MG, UAT } & \text { SAT } & \text { No-load condition } & \text { A' phase open } \\ 17 & \text { Normal operation } & \text { MG, UAT } & \text { SAT } & \text { No-load condition } & \text { A, B' phase open } \\ 18 & \text { Normal operation } & \text { MG, UAT } & \text { SAT } & \text { No-load condition } & \text { A' phase (with high-impedance ground fault) } \\ 19 & \text { Hot-standby } & \text { SAT } & \text { MT } & \text { No-load condition } & \text { A' phase open } \\ 20 & \text { Hot-standby } & \text { SAT } & \text { MT } & \text { No-load condition } & \text { A, B' phase open } \\ 21 & \text { Hot-standby } & \text { SAT } & \text { MT } & \text { No-load condition } & \text { A' phase (with high-impedance ground fault) }\end{array}$

\subsection{OPC event simulations}

\subsubsection{ETAP modeling.}

Fig. 1 shows the onsite/offsite power system models to which ETAP simulations were applied based on the configuration of the foregoing power system. Followed is the configuration of each model.

- The offsite power system consists of a $345 \mathrm{kV}$ switchyard (1)).

- The main power system consists of $1 \mathrm{MT}$ ((2)), $1 \mathrm{MG}$ ((3)), 2 UATs (4)), and 2 SATs ((5)).

- The onsite power system consists of 4 Non-1E $13.8 \mathrm{kV}$ buses ((6)), 4 Non-1E $4.16 \mathrm{kV}$ buses (7)), and 2 Class $1 \mathrm{E} 4.16 \mathrm{kV}$ buses (8)). They can be supplied with power through UAT or SAT.

- $\quad$ Each of two Class $1 \mathrm{E} 4.16 \mathrm{kV}$ buses is connected with EDG (9)).
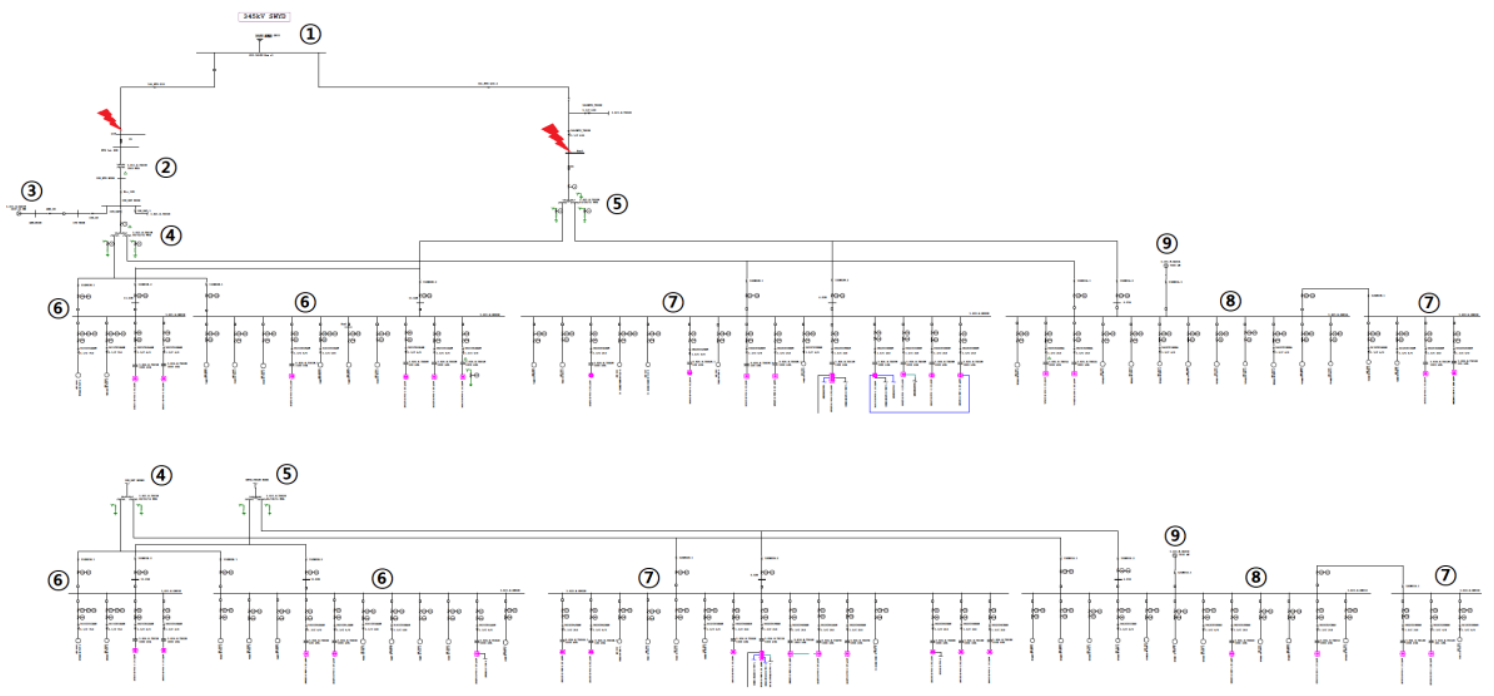

Fig. 1. ETAP modeling of target nuclear power system.

\subsubsection{Implementation plan of ETAP simulations.}

i. ETAP system was modeled to meet the conditions of each scenario (power-delivery transformer, load factor, etc) and performed load flow prior to unbalanced load flow.

ii. The tap values of the relevant transformer were converted based on the result values of load flow and the voltage of each bus (Class- $1 \mathrm{E} 4.16 \mathrm{kV}$ bus, Non-1E $13.8 \mathrm{kV}$ bus, and the low-side of MT) was adjusted to the reference value for the initial setting.

iii. After the initial setting, unbalanced load flow was performed base on each detailed scenario. 


\subsection{The results of ETAP simulations}

Table 7. Shows the results of ETAP simulations of each cases.

\begin{tabular}{|c|c|c|c|c|c|c|c|c|c|c|c|c|c|c|}
\hline \multirow{2}{*}{$\begin{array}{l}\text { Case } \\
\text { No. }\end{array}$} & \multicolumn{4}{|c|}{$\begin{array}{l}\text { Non-1E } 13.8 \mathrm{kV} \text { bus } \\
\text { voltage }(\%)\end{array}$} & \multicolumn{4}{|c|}{$\begin{array}{c}\text { Class-1E } 4.16 \mathrm{kV} \text { bus } \\
\text { voltage }(\%)\end{array}$} & \multicolumn{4}{|c|}{$\begin{array}{l}\text { Non-1E } 4.16 \mathrm{kV} \text { bus } \\
\text { voltage }(\%)\end{array}$} & \multirow{2}{*}{$\begin{array}{c}\text { Transforme } \\
\text { (MT/SAT) } \\
\text { primary } \\
\text { current(A) }\end{array}$} & \multirow{2}{*}{$\begin{array}{c}\text { Main } \\
\text { generator / } \\
\text { Bus moter } \\
\text { current(A) }\end{array}$} \\
\hline & $\mathrm{V}_{\mathrm{ab}}$ & $\mathrm{V}_{\mathrm{bc}}$ & $\mathrm{V}_{\mathrm{ca}}$ & $\mathrm{V}_{2}$ & $\mathrm{~V}_{\mathrm{ab}}$ & $\mathrm{V}_{\mathrm{bc}}$ & $\mathrm{V}_{\mathrm{ca}}$ & $\mathrm{V}_{2}$ & $\mathrm{~V}_{\mathrm{ab}}$ & $\mathrm{V}_{\mathrm{bc}}$ & $\mathrm{V}_{\mathrm{ca}}$ & $\mathrm{V}_{2}$ & & \\
\hline $\begin{array}{l}1 \\
2\end{array}$ & 117 & 99 & 87 & 18 & 117 & 100 & 87 & 17 & 117 & 100 & 87 & 18 & 0 & $24078 / 305$ \\
\hline 3 & 114 & 99 & 88 & 15 & 114 & 100 & 89 & 15 & 115 & 100 & 89 & 15 & 0 & $20903 / 265$ \\
\hline 4 & 48 & 88 & 81 & 23 & 48 & 84 & 79 & 22 & 48 & 86 & 80 & 22 & 0 & $0 / 0$ \\
\hline 5 & 0 & 0 & 0 & 0 & 0 & 0 & 0 & 0 & 0 & 0 & 0 & 0 & 0 & $0 / 404$ \\
\hline 6 & 39 & 85 & 69 & 27 & 38 & 81 & 67 & 25 & 38 & 83 & 68 & 26 & 0 & $0 / 469$ \\
\hline 7 & 82 & 98 & 95 & 10 & 82 & 96 & 94 & 9 & 82 & 97 & 95 & 9 & 91 & $0 / 163$ \\
\hline 8 & 0 & 46 & 46 & 26 & 0 & 42 & 42 & 24 & 0 & 43 & 43 & 25 & 268 & $0 / 457$ \\
\hline 9 & 59 & 94 & 81 & 20 & 58 & 91 & 80 & 19 & 58 & 92 & 81 & 19 & 200 & $0 / 353$ \\
\hline 10 & 97 & 99 & 98 & 1 & 97 & 99 & 98 & 1 & 97 & 99 & 98 & 1 & 0 & $0 / 24$ \\
\hline 11 & 0 & 0 & 0 & 0 & 0 & 0 & 0 & 0 & 0 & 0 & 0 & 0 & 0 & $0 / 0$ \\
\hline 12 & 79 & 96 & 92 & 10 & 80 & 96 & 92 & 10 & 79 & 96 & 92 & 10 & 0 & $0 / 174$ \\
\hline 13 & 99 & 100 & 100 & 1 & 99 & 100 & 100 & 1 & 99 & 100 & 100 & 1 & 5 & $0 / 8$ \\
\hline 14 & 0 & 43 & 43 & 25 & 0 & 42 & 42 & 25 & 0 & 43 & 43 & 25 & 258 & $0 / 434$ \\
\hline 15 & 79 & 98 & 94 & 11 & 79 & 98 & 94 & 11 & 79 & 98 & 94 & 11 & 110 & $0 / 195$ \\
\hline 16 & 100 & 100 & 100 & 0 & 101 & 101 & 101 & 0 & 101 & 101 & 101 & 0 & 1 & $0 / 0$ \\
\hline 17 & 100 & 100 & 100 & 0 & 101 & 101 & 101 & 0 & 101 & 101 & 101 & 0 & 0 & $0 / 0$ \\
\hline 18 & 100 & 100 & 100 & 0 & 101 & 101 & 101 & 0 & 101 & 101 & 101 & 0 & 182 & $0 / 0$ \\
\hline 19 & 100 & 100 & 100 & 0 & 100 & 100 & 100 & 0 & 100 & 100 & 100 & 0 & 0 & $0 / 0$ \\
\hline 20 & 100 & 100 & 100 & 0 & 100 & 100 & 100 & 0 & 100 & 100 & 100 & 0 & 0 & $0 / 0$ \\
\hline 21 & 100 & 100 & 100 & 0 & 100 & 100 & 100 & 0 & 100 & 100 & 100 & 0 & 0 & $0 / 0$ \\
\hline
\end{tabular}

\section{Detectability Analysis of Protective Relay}

Based on the results of the simulations above, the characteristics of the relevant protective relay were compared with them to analyze its capacity to detect OPC events. Table 8 shows the final analysis results of each case.

Table 8 . Detectability analysis of protective relay by case.

\begin{tabular}{|c|c|c|c|c|c|c|}
\hline \multirow{2}{*}{ Case No. } & \multicolumn{6}{|c|}{ Relay type } \\
\hline & 46 & $51 \mathrm{GN}$ & 27P, LU, LS & $27 \mathrm{~S}$ & 27M, LU, LS & 47 \\
\hline Case 1 & $\mathrm{O}$ & $\mathrm{X}$ & $\mathrm{X}$ & $\mathrm{X}$ & $\mathrm{X}$ & $\mathrm{O}$ \\
\hline Case 2 & - & - & - & - & - & - \\
\hline Case 3 & $\mathrm{O}$ & $\mathrm{X}$ & $\mathrm{X}$ & $\mathrm{X}$ & $\mathrm{X}$ & $\mathrm{O}$ \\
\hline Case 4 & $\mathrm{O}$ & $\mathrm{X}$ & $\mathrm{O}$ & $\mathrm{O}$ & $\mathrm{O}$ & $\mathrm{O}$ \\
\hline Case 5 & $\mathrm{X}$ & $\mathrm{X}$ & $\mathrm{O}$ & $\mathrm{O}$ & $\mathrm{O}$ & $\mathrm{X}$ \\
\hline Case 6 & $\mathrm{O}$ & $\mathrm{X}$ & $\mathrm{O}$ & $\mathrm{O}$ & $\mathrm{O}$ & $\mathrm{O}$ \\
\hline Case 7 & $\mathrm{O}$ & $\mathrm{O}$ & $\mathrm{X}$ & $\mathrm{O}$ & $\mathrm{X}$ & $\mathrm{O}$ \\
\hline Case 8 & $\mathrm{O}$ & $\mathrm{O}$ & $\mathrm{O}$ & $\mathrm{O}$ & $\mathrm{O}$ & $\mathrm{O}$ \\
\hline Case 9 & $\mathrm{O}$ & $\mathrm{O}$ & $\mathrm{O}$ & $\mathrm{O}$ & $\mathrm{O}$ & $\mathrm{O}$ \\
\hline Case 10 & $\mathrm{X}$ & $\mathrm{X}$ & $\mathrm{X}$ & $\mathrm{X}$ & $\mathrm{X}$ & $\mathrm{X}$ \\
\hline Case 11 & $\mathrm{X}$ & $\mathrm{X}$ & $\mathrm{O}$ & $\mathrm{O}$ & $\mathrm{O}$ & $\mathrm{X}$ \\
\hline Case 12 & $\mathrm{O}$ & $\mathrm{X}$ & $\mathrm{X}$ & $\mathrm{O}$ & $\mathrm{X}$ & $\mathrm{O}$ \\
\hline Case 13 & $\mathrm{X}$ & $\mathrm{X}$ & $\mathrm{X}$ & $\mathrm{X}$ & $\mathrm{X}$ & $\mathrm{X}$ \\
\hline Case 14 & $\mathrm{O}$ & $\mathrm{O}$ & $\mathrm{O}$ & $\mathrm{O}$ & $\mathrm{O}$ & $\mathrm{O}$ \\
\hline Case 15 & $\mathrm{O}$ & $\mathrm{O}$ & $\mathrm{X}$ & $\mathrm{O}$ & $\mathrm{X}$ & $\mathrm{O}$ \\
\hline Case 16 & $\mathrm{X}$ & $\mathrm{X}$ & $\mathrm{X}$ & $\mathrm{X}$ & $\mathrm{X}$ & $\mathrm{X}$ \\
\hline Case 17 & $\mathrm{X}$ & $\mathrm{X}$ & $\mathrm{X}$ & $\mathrm{X}$ & $\mathrm{X}$ & $\mathrm{X}$ \\
\hline Case 18 & $\mathrm{X}$ & $\mathrm{O}$ & $\mathrm{X}$ & $\mathrm{X}$ & $\mathrm{X}$ & $\mathrm{X}$ \\
\hline Case 19 & $\mathrm{X}$ & $\mathrm{X}$ & $\mathrm{X}$ & $\mathrm{X}$ & $\mathrm{X}$ & $\mathrm{X}$ \\
\hline Case 20 & $\mathrm{X}$ & $\mathrm{X}$ & $\mathrm{X}$ & $\mathrm{X}$ & $\mathrm{X}$ & $\mathrm{X}$ \\
\hline Case 21 & $\mathrm{X}$ & $\mathrm{X}$ & $\mathrm{x}$ & $\mathrm{X}$ & $\mathrm{X}$ & $\mathrm{X}$ \\
\hline
\end{tabular}




\subsection{Case 1}

MT negative overcurrent protective relay (346) runs and the circuit breaker of the generator shuts down. And then power is supplied to the onsite power system through UAT. Non-1E $13.8 \mathrm{kV}$ bus negative sequence overcurrent relay (246) runs and the high voltage motor load shuts down. The negative sequence overcurrent relay (47) of all buses runs and an alarm is issued to main control room.

\subsection{Case 2}

MT High-voltage side of the target nuclear power plant is not grounded while in operation. As for 2phase OPC, which has been estimated to happen when MT is not grounded (MG supplies power through the main transformer), low voltage restoration didn't occur, so it was impossible to carry on ETAP analysis. It was only estimated that Case 2 would show more conservative phenomenon than Case 1.

\subsection{Case 3}

MG negative overcurrent protective relay (346) runs and the circuit breaker of the generator shuts down. And then power is supplied to the onsite power system through UAT. Non-1E $13.8 \mathrm{kV}$ bus negative sequence overcurrent relay (246) runs and the high voltage motor load shuts down. The negative sequence overcurrent relay (47) of all buses runs and an alarm is issued to main control room.

\subsection{Case 4}

Class-1E bus under voltage relays (27M, LS, LU) run and EDG mobilizes. And the incomming breaker of the Class-1E high voltage circuit breaker panel shuts down. Non-1E bus under voltage relays (27M, LS, LU) run and an alert is issued to the main control room. And the high voltage motor connected to bus shuts down. The negative sequence overcurrent relay (47) of all buses runs and an alarm is issued to main control room. Non-1E $13.8 \mathrm{kV}$ bus negative sequence overcurrent relay (246) runs and the high voltage motor load shuts down.

\subsection{Case 5}

Class-1E bus under voltage relays (27M, LS, LU) run and EDG mobilizes. And the incomming breaker of the Class-1E high voltage circuit breaker panel shuts down. Non-1E bus under voltage relays (27M, LS, LU) run and an alert is issued to the main control room. And the high voltage motor connected to bus shuts down.

\subsection{Case 6}

All protective relays run. Class-1E bus under voltage relays (27M, LS, LU) run and EDG mobilizes. And the incomming breaker of the Class-1E high voltage circuit breaker panel shuts down. Non-1E bus under voltage relays (27M, LS, LU) run and an alert is issued to the main control room. And the high voltage motor connected to bus shuts down. The negative sequence overcurrent relay (47) of all buses runs and an alarm is issued to main control room. Non-1E $13.8 \mathrm{kV}$ bus negative sequence overcurrent relay (246) runs and the high voltage motor load shuts down.

\subsection{Case 7}

Neutral overcurrent relay (551GN) on SAT high voltage side runs and an alert is issued to the main control room. Class-1E bus (A) low voltage relay (27S) runs and EDG mobilizes. And the incomming breaker of the Class-1E high voltage circuit breaker panel shuts down. The negative sequence overcurrent relay (47) of all the buses on SAT (site 1) where OPC occurred runs and an alert is issued to the main control room. Non-1E $13.8 \mathrm{kV}$ bus (M) negative sequence overcurrent relay (246) runs and the high voltage motor load shuts down. The voltage on SAT (site 2) where OPC didn't occur maintains normal and the relay does not run. 


\subsection{Case 8}

Neutral overcurrent relay $(551 \mathrm{GN})$ on SAT high voltage side runs and an alert is issued to the main control room. Class-1E bus (A) under voltage relays (27P, S, LU, LS) run and EDG mobilizes. And the incomming breaker of the Class-1E high voltage circuit breaker panel shuts down. Non-1E bus (M) under voltage relays (27M, LS, LU) on SAT (site 1) where OPC occurred run and an alert is issued to the main control room. And the high voltage motor connected to bus shuts down. The negative sequence overcurrent relay (47) of all the buses on SAT (site 1) where OPC occurred runs and an alert is issued to the main control room. Non-1E $13.8 \mathrm{kV}$ bus (M) negative sequence overcurrent relay (246) runs and the high voltage motor load shuts down. The voltage on SAT (site 2) where OPC didn't occur maintains normal and the relay does not run.

\subsection{Case 9}

Neutral overcurrent relay (551GN) on SAT high voltage side runs and an alert is issued to the main control room. Class-1E bus (A) under voltage relays (27P, S, LU, LS) run and EDG mobilizes. And the incomming breaker of the Class-1E high voltage circuit breaker panel shuts down. Non-1E bus (M) under voltage relays (27M, LS, LU) on SAT (site 1) where OPC occurred run and an alert is issued to the main control room. And the high voltage motor connected to bus shuts down. The negative sequence overcurrent relay (47) of all the buses on SAT (site 1) where OPC occurred runs and an alert is issued to the main control room. Non- $1 \mathrm{E} 13.8 \mathrm{kV}$ bus (M) negative sequence overcurrent relay (246) runs and the high voltage motor load shuts down. The voltage on SAT (site 2) where OPC didn't occur maintains normal and the relay does not run.

\subsection{Case 10}

There is no protective relay to detect 1-phase OPC on MT high voltage side in low load.

\subsection{Case 11}

Class-1E bus under voltage relays (27P, S, LU, LS) run and EDG mobilizes. And the incomming breaker of the Class-1E high voltage circuit breaker panel shuts down. Non-1E bus under voltage relays (27M, LS, LU) run and an alert is issued to the main control room. And the high voltage motor connected to bus shuts down.

\subsection{Case 12}

Class-1E bus low voltage relay (27S) runs and EDG mobilizes. And the incomming breaker of the Class-1E high voltage circuit breaker panel shuts down. The negative sequence overcurrent relay (47) of all buses runs and an alarm is issued to main control room. Non-1E $13.8 \mathrm{kV}$ bus negative sequence overcurrent relay (246) runs and the high voltage motor load shuts down.

\subsection{Case 13}

There is no protective relay to detect 1-phase OPC on SAT high voltage side in low load.

\subsection{Case 14}

Neutral overcurrent relay (551GN) on SAT high voltage side runs and an alert is issued to the main control room. Class-1E bus (A) under voltage relays (27P, S, LU, LS) run and EDG mobilizes. And the incomming breaker of the Class-1E high voltage circuit breaker panel shuts down. Non-1E bus (M) under voltage relays (27M, LS, LU) on SAT (site 1) where OPC occurred run and an alert is issued to the main control room. And the high voltage motor connected to bus shuts down. The negative sequence overcurrent relay (47) of all the buses on SAT (site 1) where OPC occurred runs and an alert is issued to the main control room. Non-1E $13.8 \mathrm{kV}$ bus (M) negative sequence overcurrent relay (246) runs and the high voltage motor load shuts down. The voltage on SAT (site 2) where OPC didn't occur maintains 
normal and the relay does not run.

\subsection{Case 15}

Neutral overcurrent relay (551GN) on SAT high voltage side runs and an alert is issued to the main control room. Class-1E bus (A) low voltage relay (27S) runs and EDG mobilizes. And the incomming breaker of the Class-1E high voltage circuit breaker panel shuts down. The negative sequence overcurrent relay (47) of all the buses on SAT (site 1) where OPC occurred runs and an alert is issued to the main control room. Non-1E $13.8 \mathrm{kV}$ bus (M) negative sequence overcurrent relay (246) runs and the high voltage motor load shuts down. The voltage on SAT (site 2) where OPC didn't occur maintains normal and the relay does not run.

\subsection{Case 16, 17}

In case that 1-phase OPC and 1-phase OPC occur on SAT high voltage side at no load, all buses maintain normal and thus the protective relay cannot detect the OPC events.

\subsection{Case 18}

Like Case 16 and 17, all the protective relays of load bus cannot detect OPC but SAT high voltage side Neutral overcurrent relay $(551 \mathrm{GN})$ runs when accompanied with line-to-ground fault, and an alert is issued to the main control room.

\subsection{Case 19, 20 and 21}

In case that 1-phase OPC and 1-phase OPC occur on MT high voltage side at no load, all buses maintain normal and thus the protective relay cannot detect the OPC events.

\section{Conclusion}

When the electric transformer runs under heavy load, the relevant protective relay(s) can probably detect OPC event depending on the type of the event. It means it cannot detect all events and thus it is likely that abnormal power can be supplied to the offsite load. For Non-1E $13.8 \mathrm{kV}$ bus, the high voltage motor shuts down due to reverse current caused by unbalanced voltage, but abnormal power can be supplied to a non-motor load.

When the electric transformer runs under light load, the unbalance of current and voltage by OPC is minor. Particularly, when there is 1-phase open phase at offsite power system, existing protective relay(s) cannot probably detect OPC

When the electric transformer runs at no load, Class-1E bus and Non-1E bus do not have the unbalance of current and voltage and thus it does not affect onsite power system. However, open phase current that does not detect OPC makes automatic power transfer, which can lead to an event.

In conclusion, when OPC happens to the offsite power system, an existing protective relay may not function (detect) depending on the operation mode of a nuclear power plant and thus Class-1E bus can get damaged. Therefore, a separate protective system needs to detect such event in case it may happen.

It is expected that the findings of this study can be used as the basic technical data necessary to develop and improve a protective relay system in the onsite/offsite power system for a nuclear power plant and establish a regulatory policy.

\section{Acknowledgments}

This work was supported by the Nuclear Safety Research Program through the Korea Foundation of Nuclear Safety(KoFONS) using the financial resource granted by the Nuclear Safety and Security Commission(NSSC) of the Republic of Korea. (No. 1305001) 


\section{References}

[1] WANO 2015 Significant Operating Experience Report SOER 2015-1 Rev 1

[2] IAEA 2016 Impact of Open Phase Conditions on Electrical Power Systems of Nuclear Power Plants Safety Reports Series No.91

[3] NRC 2012 Design Vulnerability in Electric Power System BL 2012-01

[4] NRC 2015 Open Phase Conditions in Electric Power System NUREG-0800 Standard Review Plan BTP 8-9 Rev.0

[5] Operation Technology Inc. 2014 ETAP 12.6 User Guide

[6] EPRI 2014 Interim Report: EPRI Open-Phase Detection Method 3002004432 TECHNICAL REPORT

[7] WANO 2015 Safety Challenges from Open Phase Events SOER 2015-1 Rev 1

[8] EPRI 2013 Nuclear Maintenance Application Center: Development and Analysis of an Open Phase Detection Scheme for Various Configurations of Auxiliary Transformers 30020007642013 TECHNICAL REPORT

[9] NRC 2012 Design Vulnerability in Electric Power System: Summary Report NRC BULLETIN 2012-01

[10] NRC 2012 Design Vulnerability in Electric Power System NRC BULLETIN 2012-01 